\title{
DINAMICA NUMERICĂA POPULAȚIEI VULPII (VULPES VULPES) ÎN ECOSISTEMELE REPUBLICII MOLDOVA
}

https://doi.org/10.53937/9789975315975.22

\section{Savin Anatol}

Institutul de Zoologie al MECC, Chișinău, R.Moldova, e-mail: savin.an1948@mail.ru

Prădătorii, consumând selectiv anumite grupe de vârstă și sex, minimalizează durata vieții și în final intensitatea și eficacitatea reproducerii prăzii, fapt destul de evident la fazele de declin numeric al speciilor pradă. Astfel, prădători nu doar reduc efectivul prăzii, dar și modifică structura și productivitatea populației acesteia. Vulpea, cu o valență ecologică mare, se adaptează ușor atât la condițiile variabile ale agrocenozelor moderne, populând frecvent câmpurile agricole și cele neprelucrate, zonele de ecoton ale localităților și biotopurilor arboricole (perdele de protecție, păduri insulare) și acva-palustre, cât și la cele existente în localități și trupuri mari de păduri (Юргенсон,1973; Шилова, 1999). Schimbul informațional intens cu biota, caracteristic vulpii ca specie euribiontă și polifagă, asigură, în măsura particularităților ecologice, etologice și zoopsihologice, popularea localităților. Mediul antropic variabil prin mozaicitatea sa și factorul de deranj asigură stabilitatea trofică de origine antropică în perioada de iarnă și la fazele de depresie a resursei trofice tradiționale - rozătoarele mici (Владимирова, 2004), astfel capabil să mențină aici o densitate sporită a vulpii. Studiul spectrului trofic al vulpii în ecosistemele naturale (Юргенсон, 1968) arată că frecvența iepurelui de câmp în probe alcătuiește 10\% în perioada reproducrivă și circa 15\% în perioada de iarnă. Astfel, la o densitate superioară celei optimale (1-2 vulpi la 1 mie ha) în ecosisteme populate de iepure, vulpea este unul din factorii principali în dereglările ofensive a oscilațiilor numerice ale acestei specii.

Pentru elaborarea unor măsuri raționale de gestionare a populației prădătorilor și în particular a vulpii, sunt necesare date privind dinamica 
numerică a populației, structura și distribuția spațial-biotopică, particularitățile de adaptare la diverse condiții ale mediului. Studiul dinamicii efectivului de vulpi pe parcursul ultimilor ani demonstrează o fluctuație numerică dependentă, corelându-se pozitiv $(R c=0,71)$ cu baza trofică tradițională - rozătoarele mici, cât și cu intensitatea extragerii ei, atât în perioada de vânătoare, dar și pe parcursul întregului an (fig.1).

Efectivul destul de ridicat de vulpi se explică și prin extinderea bazei trofice din contul păsărilor domestice crescute în libertate în împrejurimile comunelor și în albiile râuleţelor și a condiţiilor de adăpost create pe câmpurile neprelucrate. Se constată o adaptare rapidă a speciei la condiţiile antropice actuale, populând frecvent localităţile, unde găsește adăpost și resurse trofice.

Densitatea vizuinilor este un parametru ce corelează pozitiv $(R c=0,61)$ cu efectivul speciei în ecosistem, iar la o vizuină reproductivă sunt înregistrate 4-8 vizuini active (Чиркова, 1952).

Cercetările noastre au arătat că în agrocenozele republicii o vizuină reproductivă este distribuită la circa 500 ha, unde în mediu populează primăvara 3 vulpi.

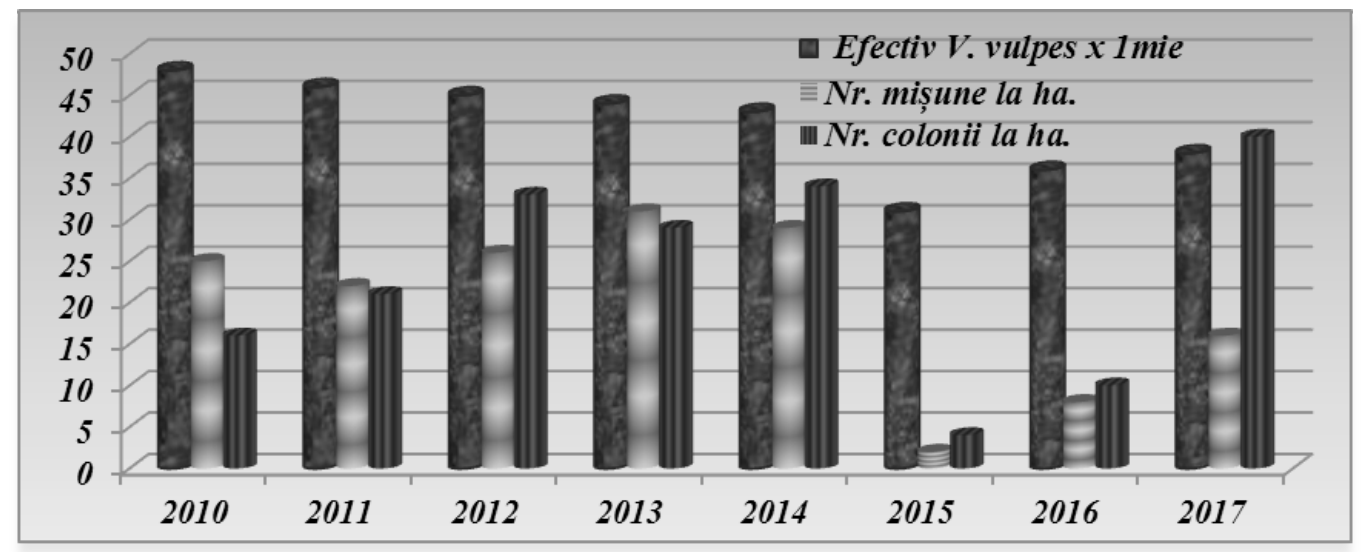

Figura 1. Dinamica corelației efectivului (mii specimene) populației vulpii și a rozătoarelor mici dominante (Mus spicilegus, Microtus sp.) în terenurile deschise ale agrocenozelor 
Evaluarea populației vulpii în primăvara anului 2018 după numărul vizuinilor reproductive (cca 5 mii), a permis de a stabili efectivul numeric în stocul reproductiv al acestui prădător la cca 15 mii specimene cu o densitate medie în ecosistemele agrare de 6 sp. la 1000 ha (variind de la 2 la 24 sp./1000 ha). Constatăm prezența în stocul reproductiv a circa 5 mii vulpi în ecosistemele silvice cu densități de peste 12 sp./1000 ha și peste 3000 vulpi ce populează cca 1,7 mii localități. Concentrarea vulpii în ecosistemele împădurite și în localități este o adaptare ecologo-etologică cauzată de baza trofică și factorul de stabilitate caracteristic acestor ecosisteme. Astfel, vulpea în perioada de reproducere are un efectiv de circa 23 mii specimene la cei 171 mii de iepuri de câmp estimați, cu un coraport catastrofal de o vulpe la 7,4 iepuri (optimal 1:70), atât prin relațiile ei de consum trofic, cât și prin exercitarea unui pres major de deranj în perioada reproductivă.

Studiul potențialului reproductiv a arătat că reproducerea, în acest an, întârzie cu 10-12 zile și circa 40\% de femele nu participă în reproducere, fertilitatea variază de la 2 la 6 embrioni. Acești parametri pot provoca un spor anual de circa 60\% și o creștere către toamnă până la 35 mii vulpi. Pentru a urmări o diminuare stabilă a efectivului populației acestui prădător este necesară o extragere anuală integrală a sporului anual (12 mii sp.) $+20 \%$ din stocul reproductiv (4,6 mii sp.) - deci circa 17 mii vulpi în comparație cu 11 mii vulpi ce alcătuiesc pierderile actuale ale populației în perioada de iarnă.

Studiul rolului vulpilor în circulația invaziilor parazitare demonstrează că vulpea ca gazdă definitivă în răspândirea biohelminților reprezintă factorul principal în circulația formelor invazionale în ecosisteme ( $F=$ 90\%). Abundența masivă a vulpii în diverse biocenoze, grație plasticității ecologice și capacității sporite de adaptare la condițiile antropice, inclusiv popularea localităților, au impact major în formarea, menținerea și răspândirea focarelor de parazitoze cu impact zoonotic și epizootic în diferite ecosisteme naturale și antropizate, la rând cu diminuarea productivității biologice a populațiilor speciilor de interes cinegetic.

Studiul a fost efectuat în cadrul proiectului fundamental 15.187.0211F. 